(C) Copyright 2019: Editum. Servicio de Publicaciones de la Universidad de Murcia. Murcia (Spain) ISSN print edition: 0212-9728. ISSN on line edition (http://revistas.um.es/analesps): 1695-2294. On line edition License Creative Commons 4.0: BY-NC-ND

\title{
Exposure to traumatic events and perceptual priming in forcedly displaced Colombian population in Ecuador
}

\author{
Carlos Reyes-Valenzuela ${ }^{1, *}$, María José Martos-Méndez², Amalio Blanco ${ }^{3}$, and Rubén Blanco ${ }^{4}$ \\ 1 Programa Andino de Derechos Humanos, Universidad Andina Simón Bolivar (Ecuador) \\ 2 Facultad de Psicología y Logopedia, Universidad de Málaga (Spain) \\ 3 Facultad de Psicología, Universidad Autónoma de Madrid (Spain) \\ 4 Hospital Universitario "Ramón y Cajal" (Spain)
}

\begin{abstract}
Título: Exposición a eventos traumáticos y priming perceptivo en población colombiana con desplazamiento forzado en Ecuador.

Resumen: Los recientes estudios en priming perceptivo se han centrado en identificar las diferencias entre población con y sin Trastorno por Estrés Postraumático (TEPT) confirmando la hipótesis que el TEPT representa un trastorno de la memoria. En este trabajo, se pretende abordar el priming en personas que han estado expuestas a diversas experiencias traumáticas relacionadas con el desplazamiento forzado. Para ello, se diseñaron tres categorías de palabras "trauma" (i.e., de amenaza, emocional y judicial) y una categoría de palabras "neutra", las cuales compartían su raíz de tres letras. Participaron 44 colombianos refugiados y solicitantes de asilo que residen en Ecuador con presencia o ausencia de TEPT. Los resultados confirman que las personas con TEPT presentan mayor priming perceptivo en las categorías de amenaza y emociones y los solicitantes de asilo en la categoría judicial. Se discuten las implicaciones para los estudios que abordan el impacto de violencia política.

Palabras clave: priming perceptivo; compleción de raíces de palabras; trastorno por estrés postraumático; desplazamiento forzado.
\end{abstract}

\section{Introduction}

Since the mid-1990s, more and more attention has been paid at the role of cognitive processes in the diagnosis of PostTraumatic Stress Disorder (PTSD) following the fourth version of the DSM (American Psychiatric Association (APA), 1994). The attention has been focused on memory issues following changes in Criterion $A$, in a special way on an unexplored memory mechanism: the relationship between PTSD symptomatology and implicit memory. Perceptual priming in populations with PTSD (Amir, McNally, \& Wiegartz, 1996; Ehring \& Ehlers, 2011; Michael, Ehlers, \& Halligan, 2005) was the main research issue. According to Tulving, Schacter and Stark (1982) "priming refers to facilitative effects of an encounter with a stimulus on subsequent processing of the same stimulus (direct priming) or a related stimulus (indirect priming)" (p. 336). Specifically in PTSD, there is particularly strong perceptual priming "for stimuli that were temporally associated with the traumatic event, i.e. there is a reduced perceptual threshold for these stimuli" (Ehlers \& Clark, 2000, p. 326).

Word-steam completion task was the initial research tool. Later on, Michael et al. (2005) and Ehring and Ehlers (2011), when exploring the differences between groups with and

* Correspondence address [Dirección para correspondencia]:

Carlos Reyes-Valenzuela. Programa Andino de Derechos Humanos, Universidad Andina Simón Bolívar, sede Ecuador. Toledo N22-80 (Plaza Brasilia) CP 1712569, Quito (Ecuador). E-mail: carlos.reyes@uasb.edu.ec (Article received: 21-12-2017; revised: 23-10-2018; accepted: 21-12-2018)
Abstract: In line with the hypothesis that PTSD is a memory disorder, recent studies on perceptual priming have focused on identifying the differences between population with and without Post-Traumatic Stress Disorder (PTSD). This study addresses priming in people who have been exposed to traumatic experiences of forced displacement. To that end, three categories of the word "trauma" (i.e., of threat, emotional and judicial) and a category of "neutral" words, which shared their three-letter root were chosen. The participants were 44 Colombian refugees and asylum seekers living in Ecuador with or without PTSD. The results of our study point that people with PTSD have higher perceptual priming in the threat and emotional categories, and asylum seekers show higher priming in the judicial category. The implications for studies that address the impact of political violence are discussed.

Keywords: perceptual priming; word-steam completion task; posttraumatic stress disorder; forced displacement.

without PTSD, used three methodological approaches: a) the traumatic and neutral words shared a three-letter root; b) the words are grouped into three categories: words related to the traumatic event experienced, words of general threat, and neutral words; and c) the free-recall task that evaluates an explicit memory is analyzed when there are no significant differences in the recollection of experimental words between the groups. There were two main findings: first, perceptual priming happens in comparing groups with and without PTSD; second, in PTSD participant's perceptual priming occurs in event related words.-

These studies have been conducted mainly in populations with and without PTSD exposed to events such as motor vehicle accidents or who were victims of sexual violence. However, no perceptual priming explorations have been carried out with populations exposed to political violence.

\section{Studies on PTSD in forcedly displaced population}

Refugees and asylum-seekers refugees are highly exposed to the PTSD, with a prevalence of over 30\% (Georgiadou, Morawa, \& Erim, 2017; Kira, Shuwiekh, Rice, Al Ibraheem, \& Aljakoub, 2017; for full review see Fazel, Wheeler, \& Danesh, 2005). However, as it is well known, self-report questionnaires overestimate the prevalence of PTSD (Fazel et al., 2005; Hollifield et al., 2002; Turner, Bowie, Dunn, Shapo, \& Yule, 2003). In addition, there is a tendency to associate refugee status and PTSD, overlooking the fact that this population presents cultural differences that the diagno- 
sis of PTSD does not grasp (Steel, Silove, Phan \& Bauman, 2002).

Recently, Colombia reached a Final Agreement for the End of Conflict and the Construction of a Stable and Lasting Peace (2016) signed between the Colombian Government and the Revolutionary Armed Forces of Colombia-People's Army (FARC), which attempts to put an end to an armed conflict that has lasted for more than six decades. More than 7 million forcibly displaced persons and more than 200,000 dead people (UNHCR, 2017; Centro Nacional de Memoria Histórica, 2013) have been victims of the armed conflict. Studies on the psychosocial effects on the population displaced by the internal conflict are mostly focused on PTSD, which ranges from $7 \%$ to $88 \%$ in this population. This high variability may be due to the size of the samples (ranging from 100 to 6,353 individuals) and the instruments used for their evaluation, which make integration and more accurate reading of the data difficult (Campos-Arias, Oviedo, \& Herazo, 2014). All the studies found that experiences of kidnapping and torture have the greatest impact on the development of PTSD.

Despite these results, epidemiological data regarding population forced to displace outside Colombia is not available. UNHCR (2017) estimates more than 60,000 refugees in Ecuador and more than 200,000 political asylum seekers. Research in similar contexts show differences in vulnerability of displaced groups according to their migration status; that is, whether they are refugees or applicants, finding out that the latter show additional stressful uncertainties such as the need to regulate their legal status in the host country (Steel et al., 2002). Aspects such as the search for housing and employment (Ibáñez \& Moya, 2006), health problems (MogollónPérez \& Vázquez-Navarrete, 2006) or exposure to exclusion and discrimination or even the presence of menacing groups in the host society have also been considered. Steel et al. (2002) state that, compared to refugees, asylum seekers are more likely to develop PTSD, given the recent emotional impact experienced in their countries of origin and the distressful uncertainty in the asylum application process. Moreover, applicants on an intensive basis demand for justice for the events they experienced, either because they filed a legal remedy in their country of origin or because they ask institutions for support in this area (Herlihy \& Turner, 2015).

For all the above reasons, the aim of this study is threefold: a) identifying the presence of PTSD in Colombian population with forced displacement residing in Ecuador; b) analyzing the differences based on migration status, and c) exploring the mechanisms of perceptual priming. Following Michael et al.'s (2005) procedure, we use the word-steam completion task according to the following categories: words that refer to a general threat, words of an emotional nature, legal terms and neutral words. The main hypotheses were as follow:

Hypothesis 1: Participants with PTSD will show higher perceptual priming than participants without PTSD in the general threat, emotional, and judicial categories.
Hypothesis 2: Asylum seekers will show higher perceptual priming than refugees in the emotional and judicial categories. No differences are expected in the general threat category.

Hypothesis 3: No differences are to be found in the free recollection test by PTSD level or by immigration status.

\section{Method}

\section{Participants}

Forty-four people with Colombian nationality who attend the institution "Asylum Access Ecuador" (AAE) in Quito participated voluntarily. ${ }^{1}$ The participants were 37 women $(84.1 \%)$ and 7 men $(15.9 \%)$ between the ages of 18 and 53 $(M=33.3$ years; $S D=9.5)$. Most of them come from the Colombian Departments of Nariño, Valle del Cauca, Huila, Caquetá and Antioquia. The main reason for leaving Colombia was the climate of extreme violence and threat from armed groups, which led them to forced displacement and subsequent asylum seeking in Ecuador, where they are under care of AAE. In terms of their migration status, $40.9 \%$ have refugee status recognized by the Ecuadorian State and 59.1\% are asylum seekers. Table 1 provides descriptive statistics for each of the socio-demographic characteristics.

Table 1. Descriptive statistics of the refugee and asylum seeker sample.

\begin{tabular}{|c|c|c|}
\hline \multirow[b]{2}{*}{ Studied variables } & \multicolumn{2}{|c|}{ Refugees and Asylum Seekers } \\
\hline & $\begin{array}{c}\text { With PTSD } \\
(n=22) \\
\end{array}$ & $\begin{array}{l}\text { Without PTSD } \\
\quad(n=22)\end{array}$ \\
\hline \multicolumn{3}{|l|}{$\overline{\text { Sex }}$} \\
\hline Male & 2 & 5 \\
\hline Female & 20 & 17 \\
\hline Age (average) & 35.3 & 31.3 \\
\hline \multicolumn{3}{|l|}{ Migration Condition } \\
\hline Refugee & 40.9 & 40.9 \\
\hline Asylum Seeker & 59.1 & 59.1 \\
\hline Time spent in Ecuador (months) & 48 & 28 \\
\hline \multicolumn{3}{|l|}{ Civil Status (\%) } \\
\hline Single & 54.5 & 54.5 \\
\hline Married & 9.1 & 4.5 \\
\hline Consensual Union & 22.7 & 36.4 \\
\hline Separated & 9.1 & 4.5 \\
\hline Widow & 4.5 & 0 \\
\hline \multicolumn{3}{|l|}{ Children (\%) } \\
\hline With Children & 95 & 72.7 \\
\hline Without Children & 5 & 27.3 \\
\hline \multicolumn{3}{|l|}{ Education Level (\%) } \\
\hline Without studies & 9.1 & 0 \\
\hline Elementary & 27.3 & 45.5 \\
\hline Secondary & 59.1 & 40.9 \\
\hline Technician-University & 4.5 & 13.6 \\
\hline \multicolumn{3}{|l|}{ Work Activity (\%) } \\
\hline Works in Ecuador & 18.2 & 54.5 \\
\hline
\end{tabular}

1 Asylum Access Ecuador (AAE) is a non-governmental organization that provides support services to refugees in Ecuador since 2007. It carries out various actions aimed at political and social spheres, as well as specific attention to displaced population in general, being the Colombian population the main beneficiary. 


\begin{tabular}{|c|c|c|}
\hline \multirow[b]{2}{*}{ Studied variables } & \multicolumn{2}{|c|}{ Refugees and Asylum Seekers } \\
\hline & $\begin{array}{l}\text { With PTSD } \\
(n=22)\end{array}$ & $\begin{array}{l}\text { Without PTSD } \\
\quad(n=22)\end{array}$ \\
\hline Does Not Work in Ecuador & 81.8 & 45.5 \\
\hline Income Level $(\%)$ & & \\
\hline Less than US\$ 318 & 90.9 & 63.6 \\
\hline More than US\$318 & 9.1 & 36.4 \\
\hline Type of Traumatic Event (\%) & & \\
\hline $\begin{array}{l}\text { Forced Displacement (plus } \\
\text { additions) }\end{array}$ & 72.7 & 65 \\
\hline Abuse & 22.7 & 25 \\
\hline Others & 4.6 & 10 \\
\hline GPTSS Score & 66.6 & 38.8 \\
\hline
\end{tabular}

\section{Procedure}

An initial meeting was held with the AAE technical team (Quito headquarters) to explain the objectives of the study. This team reviewed the material and then authorized a pilot application to 10 users, aimed at assessing the relevance and understanding of the tasks. Afterwards, the results of this application were presented to the AAE team, which allowed to initiate the implementation for all users interested in participating voluntarily.

Through posters placed in AAE, both users and visitors were invited to an individual interview. In the interview, the objectives of the study were disclosed, the participants were informed of the confidentiality of the test and read-or it was read to them-an informed consent form that they then signed. In a second phase, the experiment of perceptive priming was applied, followed by an interview guided by a questionnaire. Subsequently, after a 10 -minute break, an interview of approximately 30 minutes was conducted where participants detailed different reasons for join the AAE (e.g., concern about health problems, nightmares, persecution feelings, family problems, among others). Finally, one week later, a second interview was carried out to return the results. Bearing these considerations in mind, the selection of the sample is non-probability. Participation was voluntary and participants were identified by numerical codes that preserved anonymity in data processing.

\section{Instruments}

Socio-demographic data. Aspects such as sex, age, country of origin, civil status and educational level are taken into account.

Migration status. Information was gathered from each of the participants regarding their application for refuge in Ecuador. The possible answers were four: granted refuge, application for asylum, denial of refuge, and undocumented. For the purposes of this study, any condition in which the participant does not have granted refuge in Ecuador was categorized as an asylum seeker. The responses were therefore grouped into 1 = refugee, $2=$ asylum seeker.
Time of residence in Ecuador. They were asked about their year of arrival to Ecuador. Responses were grouped into three categories: $1=$ less than 3 years, $2=$ between 3 and 6 years and $3=$ more than 7 years.

Work status in Ecuador. There were two possible answers: $0=$ does not work and $1=$ works.

Global Post-traumatic Stress Assessment Scale (GPTSA; Crespo \& Gómez, 2012). Scale validated in Spanish population that assesses traumatic events, PTSD symptomatology and global functioning showing a list of traumatic events (e.g., natural disasters, physical violence, terrorist acts or torture, combat or exposure to war zones, imprisonment, detention or forced captivity, among others). In addition, the scale evaluates the presence and degree of incidence of symptoms in four dimensions: re-experimentation, avoidance, hyperactivation and subjective clinical symptoms. It is made up of 62 items in a Likert format, ranging from 0 (none) to 4 (extreme). The reliability obtained for this scale is very satisfactory $(\alpha=$ $.90)$.

\section{Word Steam Completion Task}

Word Selection. A total of 96 words were selected, which share a range of frequency of use in Spanish (Alameda and Cuetos, 1995). Three groups of them (12 in total) were related to traumatic experiences: words of general threat (e.g., danger, insecurity, persecution), emotional words (e.g., impotence, helplessness, resentment), and judicial words (e.g., protest, accusation, conviction). Neutral words had the same three-letter root per category (i.e., 12 for each category). Following the procedure of previous studies in perceptual priming (Ehring \& Ehlers, 2011; Michael et al., 2005), for each of these categories a neutral word was presented that shared the same range of frequency of use and the same first three letters that formed the root. This characteristic allows for competition between the "trauma" word and the "neutral" word. Finally, 12 other words were included as a way of controlling the effects of primacy and recency (Bowers \& Schacter, 1990; Michael et al., 2005).

The list of traumatic words was generated from an initial selection of 320 words, which were validated by judges with expertise in trauma. As indicated above, the words were grouped along the following categories: (a) "general threat," which is part of perceptual priming studies (Michael et al., 2005); (b) the "emotional" category was included because many words with traumatic significance are directly identified with emotions; (c) the "judicial" category was proposed by the AAE team that reported on the recurrent request for justice made by a large number of users in the early stages of the asylum application. The inter-judge validation procedure according to Kendall's $W$ had a significant level of agreement $(W=.381, p=.034)$. Thus, 36 "trauma" words were obtained, to which 60 "neutral" words were added, sharing the same three-letter root and range of frequency of use. This makes up the total number of words used in the tests. 
Coding task. Participants were shown the 96 words and were instructed to read them aloud as soon as they appeared on the screen. They were not asked to memorize them, but were informed that they were doing a concentration task. The words were presented randomly in a successive order of 3,000 milliseconds ( $\mathrm{ms}$ ) on a 14-inch HP laptop. These appeared on the screen in a central position, with a white background, font Courier New, size 18, black. Later on, there was an interval of 10 minutes for participants to perform an activity unrelated to the test.

Priming task. 48 three-letter roots were presented, corresponding to the four categories of words in the coding task. Also, the roots of the words were presented randomly and appeared in the same position, size and color as the words in the coding task. In this procedure, the answers of the participants were recorded by the interviewer on a sheet of paper.

\section{Free Recall Test}

Participants were asked to write down on the sheet of paper the words they remembered from the coding task.

\section{Results}

\section{Categorization and Data Computation}

Scoring for the "trauma" root words. For the calculation of "priming," the completed "trauma" words matching those presented during the priming task (e.g., marginalized by marginalization) were considered; words that were considered correct.

Computation of completed words. On the other hand, the "priming" computation did not take into account the completed "neutral" words that matches the experimental neutral words, since the objective was to identify the "trauma" words. However, unlike other studies already mentioned (Ehring \& Ehlers, 2011; Michael et al., 2005), analyses of all completed words and frequencies of all responses given by participants to the introduction of roots were conducted.

Priming measurement. It is the proportion of completed "trauma" words matching the words presented in the coding task.

Presence or absence of post-traumatic stress. The sample is divided into two groups based on the presence or absence of PTSD. Crespo and Gómez (2012) establish as a criterion of correction in the GPTSA test the sum of scores in intensity of symptoms in three areas: re-experimentation, avoidance and hyperactivation. ${ }^{2}$ Thus, the presence or absence of PTSD was considered by adopting the grouping criterion of the 50th percentile as cut-off point.

Group differences by PTSD level in socio-demographic condition and scales

2 For the calculation of PTSD level, the area of subjective clinical symptoms was not considered, given that previous studies on priming only include re-experimentation, avoidance and hyperactivation.
Considering that the sample of participants was reduced to the level of exposure to post-traumatic stress, several analyses were conducted on the socio-demographic variables. No differences were found in terms of sex, migration status, length of stay in Ecuador, civil status and education level (all $p>$.05). It was found that the PTSD group had more children than the non PTSD group, $\chi^{2}(N=44)=$ $4.247, p=.03$. Also, the PTSD group showed lower work activity, $\chi^{2}(N=44)=6.286, p=.01$ and lower income than the non PTSD group, $\chi 2(N=44)=5.059, p=.08$. The displacement situation was identified in most participants as the central and most traumatic event. In other cases, displacement was accompanied by other experiences (e.g., exposure to violent death of relatives, friends or meaningful others, forced detention, among others). However, when comparing one group with displacement only and another with displacement plus other traumatic events, no differences were found in the level of PTSD.

\section{Scoring of Word Steam Completions by word category}

Regarding the responses given by participants to the presentation of the root, four types of words were identified: (a) "trauma" words matching the experimental list, (b) "neutral" words matching the experimental list, (c) words not matching the experimental list, and (d) there is no response to the root. Words that did not match the experimental listing were grouped into two categories: invented "neutral" words (e.g., the word mold to the root "mol"), and invented "emotionally charged" words (e.g., the word martyrdom to the

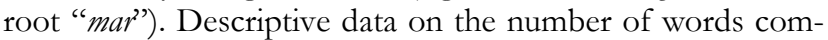
pleted by participants in each of these categories are presented below (Table 2). Participants with PTSD show more responses in the threat categories in priming words, while participants without PTSD give more invented responses in the category of judicial words.

\section{Perceptual priming based on presence or absence of PTSD}

Results are presented in Table 3. A variance analysis of 3 (categories of words) X 2 (group type) was conducted. A significant effect was found in the interaction categories of words X group type $(F(4,44)=3.042, p=.01, \eta 2 p=.01)$. Comparisons confirmed that the PTSD group showed higher priming for words related to general threat, $t(44)=$ 2.663, $p=.011, d=-.80$, and in emotional words, $t(44)=$ 2.439, $p=.019, d=-.74$ than the group without PTSD. There were no differences between the groups in terms of judicial words $(t(44)=-.446, p=.658, d=-.20)$, or neutral words $(t(44)=1.043, p=.303, d=.30)$. Thus, hypothesis 1 is partially met since, as expected, the PTSD group presented higher priming in the threat and emotional categories, but not in the judicial ones. 
Table 2. Number of words per category according to presence or absence of PTSD.

\begin{tabular}{|c|c|c|c|c|c|c|c|}
\hline \multirow[b]{3}{*}{ Category } & \multicolumn{6}{|c|}{ PTSD } & \multirow{3}{*}{$\chi^{2}$} \\
\hline & \multicolumn{3}{|c|}{$\begin{array}{l}\text { With PTSD } \\
(n=22)\end{array}$} & \multicolumn{3}{|c|}{$\begin{array}{c}\text { Without PTSD } \\
(n=22)\end{array}$} & \\
\hline & Priming & Invented & WO & Priming & Invented & WO & \\
\hline Trial & 61 & 116 & 43 & 58 & 134 & 28 & $8.43^{*}$ \\
\hline Neutral & 64 & 174 & 26 & 68 & 170 & 26 & 2.97 \\
\hline Threat & 113 & 122 & 29 & 69 & 142 & 53 & $33.12^{* * *}$ \\
\hline Emotions & 77 & 141 & 46 & 67 & 155 & 42 & 5.62 \\
\hline Judicial & 63 & 162 & 39 & 62 & 187 & 15 & $12.44^{*}$ \\
\hline Total & 378 & 715 & 183 & 324 & 788 & 164 & $27.11 * *$ \\
\hline
\end{tabular}

Note. PTSD $=$ Post-Traumatic Stress Disorder; WO = without response

$* p<.05 ; * * p<.01, * * * p<.001$

Table 3. Perceptual priming scores in categories according to PTSD presence or absence.

\begin{tabular}{lcccc}
\hline & \multicolumn{4}{c}{ PTSD } \\
\cline { 2 - 5 } & $\begin{array}{c}\text { With PTSD } \\
(n=22)\end{array}$ & \multicolumn{2}{c}{$\begin{array}{c}\text { Without PTSD } \\
(n=22)\end{array}$} \\
\cline { 2 - 5 } Priming Category & $M$ & $S D$ & $M$ & $S D$ \\
\hline Neutral & .52 & .08 & .54 & .08 \\
Threat & $.17^{*}$ & .11 & .09 & .07 \\
Emotions & $.10^{*}$ & .08 & .05 & .05 \\
Judicial & .07 & .05 & .06 & .05 \\
\hline
\end{tabular}

Note. PTSD $=$ post-traumatic stress disorder.

$* p<.05$

\section{Free recall task based on PTSD presence or absence}

Results from the free recollection task are shown in Table 4. As expected, there were no significant effects.

Table 4. Scores in free recollection task based on PTSD presence or absence.

\begin{tabular}{lllll}
\hline & \multicolumn{4}{c}{ PTSD } \\
\cline { 2 - 5 } & \multicolumn{2}{c}{ With PTSD } & \multicolumn{2}{c}{ Without PTSD } \\
$(n=22)$ & \multicolumn{2}{c}{$(n=22)$} \\
\cline { 2 - 5 } & $M$ & $S D$ & $M$ & $S D$ \\
Free Recollection & .09 & .03 & .10 & .05 \\
\hline Note. PTSD = post-traumatic stress disorder. & &
\end{tabular}

\section{Perceptual priming based on migration status}

There was no interaction between the category of the word and migration status. When comparing by migration status, no differences were found in the word categories of general threat or in words with emotional content (all $p>$ $.05)$. On the other hand, as expected, significant differences were found in the category of judicial words $(t(44)=-2.056$, $p=.04, d=-.78)$, where asylum-seeking participants exhibited higher priming. Therefore, hypothesis 2 is partially met, since while the expected difference in the judicial category is noticed, there are no differences in the emotional category. Lastly, significant differences were found regarding neutral words $(t(44)=2.707, p=.010, d=.83)$, where refugees showed higher priming. The results are presented in Table 5.
Table 5. Priming scores in categories based on migration status.

\begin{tabular}{lllll}
\hline & \multicolumn{4}{c}{ Migration Status } \\
\cline { 2 - 5 } & $\begin{array}{c}\text { Refugee } \\
(n=18)\end{array}$ & $\begin{array}{c}\text { Asylum Seeker } \\
(n=26)\end{array}$ \\
\cline { 2 - 5 } Priming Category & $M$ & $S D$ & $M$ & $S D$ \\
\hline Neutral & $.27^{*}$ & .06 & .22 & .06 \\
Threat & .13 & .13 & .13 & .08 \\
Emotional & .07 & .06 & .08 & .08 \\
Judicial & .04 & .04 & $.08^{*}$ & .06 \\
\hline Note. $* p<.05$ & & & &
\end{tabular}

Free recall task based on migration status

Table 6 shows the results in the free recollection task based on migration status. As expected, there were no significant effects $(t(42)=-1.732, p=.091, d=.09)$.

Table 6. Scores in free recollection test based on migration status.

\begin{tabular}{ccccc}
\hline & \multicolumn{4}{c}{ Migration Status } \\
\cline { 2 - 5 } & \multicolumn{2}{c}{$\begin{array}{c}\text { Refugee } \\
\text { Free Recall }\end{array}$} & \multicolumn{2}{c}{$\begin{array}{c}\text { Asylum Seeker } \\
(n=26)\end{array}$} \\
\cline { 2 - 5 } & .09 & .01 & .10 & $S D$ \\
\hline
\end{tabular}

\section{Discussion}

This study explores perceptual priming in Colombian refugees and asylum seekers residing in Ecuador, becoming the first known study to explore the effects of traumatic experiences on this population in implicit memory. Results suggest a partial confirmation of hypothesis 1 . As a matter of fact, a higher perceptual priming is found in the general threat and emotional categories in the PTSD group, but not in the judicial category. This allows for several interpretations: first, as suggested by the DSM-5 diagnostic criteria (American Psychiatric Association (APA), 2013), disorder has effects on the threat and emotional dimensions. Threat perception and high emotional instability condition the onset of PTSD. Second, the general threat category is identical to that used in previous studies (Ehring \& Ehlers, 2011; Michael et al., 2005), but contrary to their results here a correlation with the degree of priming appears. Third, the emotional category generated could be included in perceptual priming studies with samples 
that have experienced other traumatic events, regardless of whether they are related to forced displacement or political violence.

With regard to hypothesis 2 , the results by migration category confirm the discrepancies only in the judicial category. This makes it possible to strengthen Herlihy and Turner's (2015) ideas on the demand for justice by asylum-seekers. However, no differences were found in the emotional category, as suggested especially for asylum-seekers (Steel et al., 2002). The free recollection test is met in Hypothesis 3 regarding the level of PTSD and migration status, accordingly. This allows verifying once more that the differences are produced in the priming and not in direct measurements of memory, essential in this type of procedure.

On the other hand, considering exposure to other traumatic events makes it possible to identify events related to the displacement experience. This leads to a cumulative effect of trauma characterized by an excessive amount of stress and repeated exposure to the event (Kira, 2010; Kira, Templin, Lewandowski, Ashby, Oladele, \& Odenat, 2012), which means that a central traumatic experience triggers other impacts. In this case, the displacement experience becomes a central experience to which other traumatic events such as forced detention or the violent death of significant ones are often added. As a consequence, this cumulative effect (the dose hypothesis) impairs the neuropsychological performance of learning, attention and memory (Admon et al., 2009).

In the context of high and permanent vulnerability to which displaced persons are exposed, the impact on the memory of the trauma is an essential aspect of all types of mental health intervention and asylum-seeking procedures. In this case, on the one hand, it has been pointed out that there are implicit elements in the memory of this population that are affecting the processing of traumatic events, especially the perception and association with sensory details of the traumatic experience. This requires incorporation into psychosocial care plans contrasting current needs with the effects of these experiences (Beristain, 2009; Lira, 2010). On the other hand, the institutions that counsel displaced persons and the State Agency that decides their migration status in the host society must consider the cumulative effects of trauma and its impact on memory (Graham, Herlihy, \& Brewin 2014). This means that these procedures cannot be aimed solely at detecting and demonstrating the threats and

\section{References}

Admon, R., Lubin, G., Stern, O., Rosenberg, K., Sela, L., Ben-Ami, H., \& Hendler, T. (2009). Human vulnerability to stress depends on amygdala`s predisposition and hippocampal plasticity. PNAS, 106(33), 1412014125. https://doi.org/10.1073/pnas.0903183106

Alameda, J. R., \& Cuetos, F. (1995). Dictionary of unit frequencies linguistics of Castilian. Diccionario de frecuencias de las unidades lingüísticas del castellano]. Oviedo: Publications Service of the University of Oviedo.

UNHCR (2017). Colombia situation. Colombia, Ecuador and Venezuela. February 2017. [Situación Colombia. Colombia, Ecuador y Venezuela. Febrero harms suffered, but must incorporate the barriers and avoidance behaviors that displaced persons exhibit, especially in situations of sexual abuse or torture.

\section{Limitations}

Despite of word-steam completion as a useful research tool, this task does not allow reaction times to be measured. It only records responses. Thus, the evaluation of implicit processing is to be related only to the word completed by the participant and not to the latency times, an aspect that is essential to confirm the automaticity of the processing. The use of voice recording during the response emission would be required to evaluate the differences regarding this point. Another possibility is to use a version of the lexical decision test via the identification of experimental words.

A second limitation is that the criterion for measuring PTSD level is based on self-report questionnaires, which-as is well known - are often affected by responses aimed at social desirability. It would be important to complement the diagnostic results of the GPTSS through diagnostic interviews. Another aspect to evaluate in refugee and asylum-seeker populations is the aforementioned cumulative effect of trauma (Gamache, DeMarni, DePrince, \& Freyd, 2013; Kira et al., 2008) that would facilitate a comprehensive understanding of the impact of traumatic events. As noted, PTSD evaluation is insufficient to assess this type of group.

In future research, internally displaced persons remaining in Colombia should be included as a reference group to note the differences in the cumulative effect of trauma on displaced persons inside or outside the country. Likewise, it should be add measures that address both individual and collective coping strategies, and particularly religious coping (Kroo \& Nagy, 2011; Pargament \& Brant, 1998). Lastly, as stated above, displacement is associated with other events highly stressful. Therefore, it would be needed to include personal displacement experiences using qualitative methods that would allow the multiple sides of this situation to be addressed in greater detail.

Acknowledgments.- This research was supported by the IberoAmerican University Graduate Association (AUIP) and the Ministry of Economy and Knowledge of the Junta de Andalucía, as sponsors of the AUIP postdoctoral mobility program awarded to Carlos Reyes-Valenzuela. 
Amir, N., McNally, R., \& Wiegartz, P. (1996). Implicit memory bias for threat in Post-traumatic Stress Disorder. Cognitive Therapy and Research, 20, 6, 625-635. https://doi.org/10.1007/BF02227965

Beristain, C. M. (2009). Dialogues on reparation: what to repair in cases of buman rights violations. [Diálogos sobre la reparación: que reparar en los casos deviolaciones de derechos humanos]. Quito: Ministry of Justice and Human Rights.

Campo-Arias, A., \& Herazo, E. (2014). Stigma and Mental Health in Victims of Colombia's Internal Armed. Conflict in Situation of Forced Displacement [Estigma y salud mental en personas víctimas del conflicto armado interno colombiano en situación de desplazamiento forzado]. Rev. Colomb. Psiquiat, 43(4), 212-217. https://doi.org/10.1016/j.rcp.2014.09.004

Centro Nacional de Memoria Histórica, CNMH (2013). ENOUGH! Colombia: memories of war and dignity. Bogotá: National Center of Historical Memory. [jBASTA YA! Colombia: memorias de guerra y dignidad]. Bogotá: National Center of Historical Memory.

Colombia Government (2016). Final Agreement for the End of Conflict and the Construction of a Stable and Lasting Peace. [Acuerdo final para la Terminación del Conflicto y la Construcción de una Paz Estable y Duradera]. Accessed June 12, 2017.

http://www.altocomisionadoparalapaz.gov.co/procesos-yconversaciones/Documentos\%20compartidos/24-112016NuevoAcuerdoFinal.pdf.

Crespo, M., \& Gómez, M. (2012). The evaluation of post-traumatic stress: Presentation of Global Post-traumatic Stress Assessment Scale (GPTSA). [La evaluación del estrés postraumático: Presentación de la escala de evaluación global de estrés postraumático (EGEP)]. Clínica y Salud, 23(1), 25-41. http://dx.doi.org/10.5093/cl2012a4

Ehlers, A., \& Clark, A. (2000). A cognitive model of posttraumatic stress disorder. Behavior Research and Therapy, 38, 319-345. https://doi.org/10.1016/S0005-7967(99)00123-0

Ehring, T., \& Ehlers, A. (2011). Enhanced Priming for Trauma-Related Words Predicts Posttraumatic Stress Disorder. Journal of Abnormal Psychology, 120, 234-239. http://dx.doi.org/10.1037/a0021080

Fazel, M., Wheeler, J., \& Danesh, J. (2005). Prevalence of serious mental disorder in 7000 refugees resettled in western countries: a systematic review. The Lancet, 365(9467), 1309-1314. https://doi.org/10.1016/S0140-6736(05)61027-6

Gamache, C., DeMarni, L., DePrince, A. P., \& Freyd, J. J. (2013). The role of cumulative trauma, betrayal, and appraisals in understanding trauma symptomatology. Psychological Trauma: Theory, Research, Practice, and Policy, 5(2), 110-118. https://doi.org/ 10.1037 / a0025686

Georgiadou, E., Morawa, E., \& Erim, Y. (2017). High Manifestations of Mental Distress in Arabic Asylum Seekers Accommodated in Collective Centers for Refugees in Germany. International Journal of Environmental Research and Public Health, 14(6), 612. http://dx.doi.org/10.3390/ijerph14060612

Graham, B., Herlihy, J., \& Brewin, C. R. (2014). Overgeneral memory in asylum seekers and refugees. Journal of Behavior Therapy and Experimental Psychiatry, 45(3), 375-380. https://doi.org/10.1016/j.jbtep.2014.03.001
Herlihy, J., \& Turner, S. (2015). Untested assumptions: psychological research and credibility assessment in legal decision-making. European Journal of Psychotraumatology, 6, 1-5. https://doi.org/ 10.3402/ejpt.v6.27380

Hollifield, M., Warner, T. D., Lian, N., Krakow, B., Jenkins, J. H., Kesler, J. Stevenson, J., \& Westermeyer, J. (2002). Measuring trauma and health status in refugees: a critical review. The Journal of American Medical Association, 288(5), 611-621. https://doi.org/ 10.1001/jama.288.5.611

Ibáñez, A. M., \& Moya, A. (2006). How does forced displacement deteriorate the well-being of displaced households? Analysis and determinants of welfare in the reception municipalities. [¿Cómo el desplazamiento forzado deteriora el bienestar de los hogares desplazados? Análisis y determinantes del bienestar en los municipios de recepción]. Bogotá: CEDE.

Kira, I. A. (2010). Etiology and treatment of post-cumulative traumatic stress disorders in different cultures. Traumatology, 16(4), 128-141. http://dx.doi.org/10.1177/1534765610365914

Kira, I. A., Templin, T., Lewandowski, L., Ashby, J. S., Oladele, A., \& Odenat, L. (2012). Cumulative Trauma Disorder Scale (CTD): Two Studies. Psychology, $\quad 3(09), \quad$ 643-656. $\quad$ http//dx.doi.org/ 10.4236/psych.2012.39099

Kira, I. A., Shuwiekh, H., Rice, K., Al Ibraheem, B., \& Aljakoub, J. (2017). A Threatened Identity: The Mental Health Status of Syrian Refugees in Egypt and Its Etiology. Identity, 17(3), 176-190. http://dx.doi.org/10.1080/15283488.2017.1340163

Kroo, A., \& Nagy, H. (2011). Post-traumatic growth among traumatized Somali refugees in Hungary. Journal of Loss and Trauma, 16(5), 440-458. https://doi.org/10.1080/15325024.2011.575705

Lira, E. (2010). Trauma, grief, repair and memory. [Trauma, duelo, reparación y memoria]. Revista de Estudios Sociales, 36, 14-28.

Michael, T., Ehlers, A., \& Halligan, S. L. (2005). Enhanced Priming for Trauma-Related Material in Posttraumatic Stress Disorder. Emotion, 5(1), 103-112. http://dx.doi.org/ 10.1037/1528-3542.5.1.103

Mogollón-Pérez, A. S., \& Vázquez-Navarrete, M. L. (2006). Opinion of displaced women on the impact on their health of forced displacement. [Opinión de las mujeres desplazadas sobre la repercusión en su salud del desplazamiento forzado]. Gaceta Sanitaria, 20(4), 260-265.

Pargament, K. I., \& Brant, C. R. (1998). Religion and coping. In H. G. Koenig (ed.), Handbook of Religion and Mental Health (pp.111-128). New York: Academic Press.

Steel, Z., Silove, D., Phan, T., \& Bauman, A. (2002). Long-term effect of psychological trauma on the mental health of Vietnamese refugees resettled in Australia: a population-based study. The Lancet, 360(9339), 1056-1062. https://doi.org/10.1016/S0140-6736(02)11142-1

Tulving, E., Schacter, D. L., \& Stark, H. A. (1982). Priming effects in wordfragment completion are independent of recognition memory. Journal of Experimental Psychology: Learning, Memory and Cognition, 8, 336-342. http://dx.doi.org/10.1037/0278-7393.8.4.336

Turner, S. W., Bowie, C., Dunn, G., Shapo, L., \& Yule, W. (2003). Mental health of Kosovan Albanian refugees in the UK. The British Journal of Psychiatry, 182(5), 444-448. https://doi.org/10.1192/bjp.182.5.444 